\title{
Analisis Daya Dukung DAS Berdasarkan Kriteria Tata Air dan Daya Tampung Beban Pencemaran Sungai Gedek
}

\author{
Nesta Lilis Anggraeni ${ }^{1 *}$, Yusrianti ${ }^{2}$, Shinfi Wazna Auvaria ${ }^{3}$, Amrullah $^{4}$ \\ 1,2,3,4 Program Studi Teknik Lingkungan, Universitas Islam Negeri Sunan Ampel, Surabaya \\ *Koresponden email: nestaanggraeni6@gmail.com
}

Diterima: 10 Juli 2021

Disetujui: 6 Agustus 2021

\begin{abstract}
Annual population growth and rapid economic development result in environmental issues related to the use of air resources. A requirement such as condition the water system to river stream monitoringarea in which has a variated problematic environment. The purpose of this study was to determine the value of load capacity and to assess carrying capacity of the water management criteria. Based on the calculation of the pollutant loading capacity of class I, the parameters DO, COD, BOD, TSS and ammonia exceed the loading capacity of each of 3,325.07 mg/l, -9,872.32 mg/l, - 799,0063 mg/l, -271,705.21 mg/l, -664.06 $\mathrm{mg} / \mathrm{l}$. In class II, which exceeds the load capacity, the parameters DO, TSS, and ammonia are 1,425.08 $\mathrm{mg} / \mathrm{l},-262.704 .016 \mathrm{mg} / \mathrm{l},-569.0619 \mathrm{mg} / \mathrm{l}$, respectively. In class III, which exceeds the carrying capacity of the pollution load, the parameters DO, TSS, and ammonia is $475.01 \mathrm{mg} / \mathrm{l},-214.704 .016 \mathrm{mg} / \mathrm{l},-284.0558$ $\mathrm{mg} / \mathrm{l}$, respectively. In class IV, all parameters are in accordance with the polluting load capacity. The value of capacity according to the criteria of water quality, quantity, and continuity (water management) is 102.5 $\%$ included in the category.
\end{abstract}

Keywords: water management, pollutant load, pollution load capacity, water quality, water pollution

\begin{abstract}
Abstrak
Peningkatan jumlah penduduk tiap tahun serta perkembangan ekonomi yang pesat menyebabkan permasalahan lingkungan terkait penggunaan sumberdaya air. Diperlukan penilaian kondisi tata air untuk pemantauan daerah aliran sungai dalam mencegah berbagai permasalahan lingkungan. Tujuan penelitian ini adalah untuk mengetahui nilai daya tampung beban pencemaran dan menilai daya dukung pada kriteria tata air. Hasil analisis daya tampung beban pencemaran kelas I parameter yang melebihi adalah BOD, DO, COD, Amonia serta TSS masing-masing adalah -799,0063 mg/l, 3.325,07 mg/l, -9.872,32 mg/l, -664,06 $\mathrm{mg} / \mathrm{l}$, dan -271.705,21 mg/l. Pada kelas II yang melebihi daya tampung beban pencemaran yaitu DO, TSS, dan Amonia masing-masing sebesar 1.425,08 mg/l, -262.704,016 mg/l, -569,0619 mg/l. Pada kelas III parameter yang melebihi adalah DO, TSS, dan Amonia masing-masing sebesar 475,01 mg/l, -214.704,016 $\mathrm{mg} / \mathrm{l},-284,0558 \mathrm{mg} / \mathrm{l}$. Pada kelas IV semua parameter memenuhi daya tampung beban pencemaran. Nilai daya dukung berdasarkan kriteria kualias, kuantitas, dan kontinuitas air (tata air) adalah 102,5\% termasuk dalam kategori sedang.
\end{abstract}

Kata Kunci: tata air, beban pencemar, daya tampung beban pencemaran, kualitas air, pencemaran air

\section{Pendahuluan}

Daerah Aliran Sungai (DAS) merupakan daerah yang berperan penting dalam sebagai dasar dari pengelolaan sumberdaya air. Peranan yang strategis daerah aliran sungai dapat dilihat dari fungsi daerah aliran sungai itu sendiri yang tidak berfungsi optimal pada pengelolaan tata air yang dapat dilihat dari banyaknya kejadian banjir, erosi, kekeringan dan sedimentasi. Hal tersebut menjelaskan bahwa fungsi daerah aliran sungai telah terganggu. DAS pada dasarnya merupakan daerah dengan potensi konflik antar pemakai serta menyebabkan fungsi lahan berubah dan kegiatan perambahan hutan. Adanya perubahan fungsi lahan di daerah aliran sungai dapat menyebabkan penurunan tata air, sedimentasi, dan laju erosi serta fluktuasi debit aliran semakin besar pada musim kemarau maupun hujan. Oleh karena itu perlu adanya perlakuan pada daerah aliran sungai dengan menjjaga kelestarian alam di sekitar daerah aliran sungai[1] .

Danau, mata air, air rawa, dan air sungai tergolong dalam air permukan, dimana dimana ketersediaan air sangat bergantung pada daerah aliran sungai dan kondisi sumber air. Air akan tercemar dengan mudah walaupun air adalah SDA yang dapat diperbarui. Tersedianya air sebagaimana peruntukannya bergantung dengan kualitas air tersebut. Kualitas air yang baik dapat mendukung aktivitas pembangunan serta usaha seperti menyuplai air dalam memenuhi kebutuhan rumah tangga, industri, perikanan, pertanian, ataupun rekreasi [2]. 
Daerah aliran sungai Gedek memiliki luas yaitu 3233,34 Ha. Panjang sungai Gedek yaitu 6,7 km dimana melewati desa-desaantara lain Kenongo, Kebaron, Ngempla, Pangkemiri, Kepadangan dan Jiken.Terdapat beberapa industri di Kecamatan Tulangan antara lain 32 industri besar atau sedang, 178 industri sedang dan 666 industri kecil. Tercemarnya air dapat disebabkan oleh unsur yang masuk dalam perairan dan mengakibatkan penurunan kualitas air. Identifikasi kualitas air dapat dilakukan berdasarkan sifat kimiawi, fisik, dan biologi dimana kandungan zat yang tinggi maka pencemaran air air sungai maakin tinggi. Akumulasi dari zat pencemar dapat menyebabkan adanya cemaran terhadap kemampuan sungai dalam memulihkan diri kembali. Menurut PP No. 82 Tahun 2001 [3] Daya tampung beban pencemaran air adalah kemampuan sungai untuk menerima masukan bahan pencemar tanpa menyebabkan air pada sungai tersebut tercemar. Sungai Gedek diduga tercemar limbah, hal ini dapat terlihat bahwa adanya kejadian dari banyaknya ikan yang mabuk dan matim di sungai Gedek yang dikarenakan oleh limbah yang dibuang di aliran sungai. Perlunya pemantauan besarnya kandungan pencemaryang masuk ke dalam sungai Gedek, sehingga dapat menjadi gambaran kondisi kualitas air serta daya tampung yang dimiliki Sungai Gedek[4].

Berdasarkan uraian diatas maka diperlukan penelitian mengenai Analisis daya dukung DAS berdasarkan kriteria tata air dan daya tampung beban pencemaran sungai Gedek bertujuan untuk mengetahui nilai daya dukung daerah aliran sungai Gedek pada kriteria kuantitas, kualitas serta kontinuitas air sebagai upaya pemantauan kinerja DAS sekaligus upaya pencegahan kekritisan DAS akibat perubahan tata guna lahan dalam DAS dan untuk mengetahui jumlah pencemar yang diperbolehkan untuk dibuang ke sungai agar tidak melampaui daya tampung beban pencemaran.

\section{Metode Penelitian}

\section{Waktu dan Lokasi Penelitian}

Penelitian ini dilaksanakan pada bulan Maret 2021 hingga Juni 2021 di Sungai Gedek Kecamatan Tulangan Kabupaten Sidoarjo. Titik pengambilan sampel dilakukan pada 5 stasiun yaitu pada stasiun 1 di Desa Kebaron, stasiun 2 di Desa Kepadangan, stasiun 3 di Desa Kenongo, stasiun 4 di Desa Jiken dan stasiun 5 di Desa Pangkemiri. Diskripsi lokasi penelitian selanjutnya disajikan seperti pada Gambar 1.

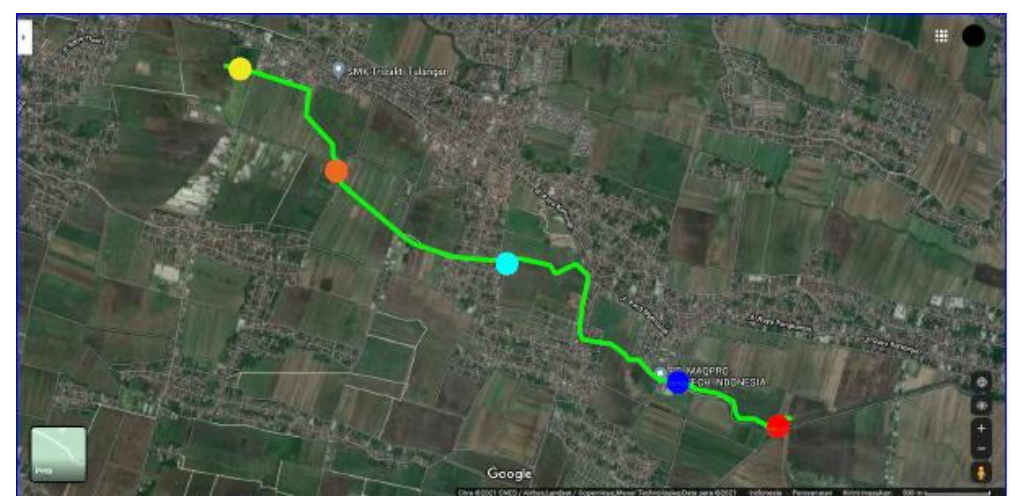

Gambar 1. Lokasi Pengambilan Sampel

Sumber: Google Maps, 2021

\section{Alat dan Bahan}

Alat-alat yang digunakan dalam pelaksanaan penelitian adalah sebagai berikut : Termometer, $\mathrm{pH}$ meter, Vertical Water Sampler, Current Meter, Meteran, Tali Rafia, Kayu, Neraca Analitik, Oven, dan software Arc GIS.

\section{Kebutuhan Data Penelitian}

Data yang digunakan dalam penelitian ini pada analisis daya dukung merupakan data sekunder Dinas Pekerjaan Pengairan dan Sumber Daya Air Kabupaten Sidoarjo, BPDAS Brantas Sampean, dan Arcgis. Data yang dibutuhkan dalam menghitung daya tampung beban pencemaran antara lain luass penampang, data kualitas air, debit aliran Sungai Gedek.

\section{Analisis Data}

Analisis data dilakukan dengan eksperimen laboratorium. Parameter yang diuji diantaranya TSS, BOD, Amonia, DO, COD, Suhu, pH. Selanjutnya hasil analisis kualitas air yang dapat dibandingkan dengan baku mutu air kelas 1,2,3,4 pada PP No. 22 Tahun 2021 [5]. Setelah itu dilakukan perhitungan daya tampung beban pencemaran. Pada analisis daya dukung dapat dilakukan dengan skoring berdasarkan Peraturan Menhut RI No.60 Menhut II 2014 [6] tentang Kriteria Penetapan Klasifikasi DAS yang focus pada kriteria tata air. 


\section{a. Daya Tampung}

Pengambilan sampel dilakukan dengan mengacu pada SNI 03-7016-2004 [7]. Pengukuran kedalaman sungai, luas penampang sungai, serta lebar sungai dilakukan secara langsung dari jembatan sungai dan sisi kanan-kiri sungai. Berikut ini merupakan rumus untuk menghitung debit aliran:

$$
\mathrm{Q}=\mathrm{A} \cdot \mathrm{V}
$$

Keterangan:

$\mathrm{Q}=$ debit aliran sungai $(\mathrm{m} 3 / \mathrm{s})$

$\mathrm{V}=$ kecepatan aliran air $(\mathrm{m} / \mathrm{dtk})$

$\mathrm{A}=$ Luas penampang basah $(\mathrm{m} 2)$

Berikut ini merupakan rumus beban pencemar perhari:

$$
\mathrm{BPS}=(\mathrm{CS}) \mathrm{j} \mathrm{x} \text { Qs } \mathrm{x} \mathrm{f}
$$

\section{Keterangan:}

$\mathrm{BPS}=$ beban pencemaran sebenarnya $(\mathrm{kg} / \mathrm{hari})$

(CS)j = kadar sebenarnya unsur pencemar $\mathrm{j}(\mathrm{mg} / \mathrm{l})$

Qs = debit aliran sungai $\left(\mathrm{m}^{3}\right.$ /hari).

Setelah diperoleh nilai beban pencemar, selanjutnya menghitung daya tampung beban pencemaran perhari dengan rumus sebagai berikut :

$$
\mathrm{DTBP}=\mathrm{BPM}-\mathrm{BPS}
$$

Keterangan:

DTBP = Daya Tampung Beban Pencemaran

$\mathrm{BPM}=$ Beban Pencemaran Maksimum

BPS = Beban Pencemaran sebenarnya.

\section{b. Daya Dukung (Tata Air)}

Kriteria tata air menjelaskan mengenai KRA (Koefisien Rejim Aliran), KAT (Koefisien Aliran Tahunan), banjir, muatan sedimen, dan penggunaan air. Nilai koefisien regim aliran didapatkan dari nilai Qmaks dengan Qmin. Nilai koefisien rejim aliran yang tinggi menjelaskan bahwa terdapat perbedaan yang besar antara Qmaks dengan Qmin, yang berarti bahwa terjadi debit yang tinggi ketika musim hujan, sedangkan debit aliran kecil saat musim kemarau. Indikator ini menunjukkan bahwa daerah aliran sungai mengalami kerusakan yang ditandai dengan daerah aliran sungai yang tidak mampu dalam meresap air hujan sehinggga mengakibatkan limpasan besar pada musim hujan serta menyebabkan cadangan air tanah sedikit saat musim kemarau [1]. Berikut ini rumus untuk menghitung koefisien rejim aliran:

$$
\mathrm{KRA}=\mathrm{Q} \max / \mathrm{Qa}
$$

\section{Keterangan :}

Qmax $=$ debit maksimum $(\mathrm{m} 3 / \mathrm{dt})$

$\mathrm{Qa}=$ debit andalan $(\mathrm{m} 3 / \mathrm{dt})$

Qrata = debit harian rata-rata

Berikut ini merupakan kriteria untuk penilaian KRA pada Tabel 1.

Tabel 1. Kriteria penilaian Koefisien Rejim Aliran (KRA)

\begin{tabular}{llll}
\hline No. & Nilai KRA & Skor & Kualitas Pemulihan \\
\hline 1. & KRA $\leq 0,5$ & 0,50 & Sangat rendah \\
2. & $0,5<$ KRA $\leq$ & 0,75 & Rendah \\
& 10 & & \\
3. & $10<$ KRA $\leq 15$ & 1,00 & Sedang \\
4. & $15<$ KRA $\leq 20$ & 1,25 & Tinggi \\
5. & KRA $>20$ & 1,50 & Sangat Tinggi \\
\hline
\end{tabular}

Sumber: Peraturan Menhut RI No.60 2014 
Koefisien Aliran Tahunan yaitu nilai tebal aliran dan tebal hujan tahunan di DAS. Koefisien Aliran Tahunan menunjukkan curah hujan yang menjadi runoff pada daerah aliran sungai. Tebal aliran merupakan volume debiy yang didapatkan dari pencatatan AWLR di daerah aliran sungai dan dibagi dengan luasan daera alran sungai, kemudian dikonversi ke satuan mm. Tinggi hujan merupakan hasil pencatatan Stasiun Penakar Hujan secara manual maupun otomatis [1]. Berikut ini merupakan kriteria KAT:

Tabel 2. Kriteria penilaian Koefisien Aliran Tahunan

\begin{tabular}{|c|c|c|c|c|}
\hline No. & $\begin{array}{l}\text { Koefisien } \\
\text { Tahunan }\end{array}$ & Aliran & Skor & $\begin{array}{l}\text { Kualifikasi } \\
\text { Pemulihan }\end{array}$ \\
\hline 1. & $\leq 0,2$ & & 0,50 & Sangat rendah \\
\hline 2. & $5<\mathrm{C} \leq 10$ & & 0,75 & Rendah \\
\hline 3. & $10<\mathrm{C} \leq 15$ & & 1,00 & Sedang \\
\hline 4. & $15<\mathrm{C} \leq 20$ & & 1,25 & Tinggi \\
\hline 5. & $C>20$ & & 1,50 & Sangat tinggi \\
\hline
\end{tabular}

Sumber: Peraturan Menhut RI No.60 2014

Sedimentasi merupakan banyaknya uinsur tanah seperti lumpur berada di perairan yang terbawa arus air dari proses erosi di hulu sungaiyang kemudian mengendap di hilr dimana kecepatan engendapan material suspensi lebih kecil daripada kecepatan angkutan. Pada proses sedimentasi, hanya sebagian material yang diangkut keluar dari DAS, sementara itu, sebagian unsur lain akan mengalami pengendapan di daerah tertentu sepanjang aliran sungai. Proses terjadinya sedimentasi dapat dilihat oleh adanya kandungan lumpur pada perairan sungai yang terangkut dalam aliran sungai. Semakin banyak kandungan sedimen yang terbawa oleh aliran maka kondisi daerah aliran sungai semakin tidak sehat [1]. Berikut ini Tabel 3 Kriteria Muatan Sedimen:

Tabel 3. Kriteria penilaian Muatan Sedimen (MS)

\begin{tabular}{llcl}
\hline No. & $\begin{array}{l}\text { Nilai } \\
\text { Sedimen } \\
\text { (Ton/ha/tahun) }\end{array}$ & & $\begin{array}{l}\text { Kualifikasi } \\
\text { Pemulihan }\end{array}$ \\
\hline 1. & $\leq 5$ & 0,50 & Sangat rendah \\
2. & $5<\mathrm{MS} \leq 10$ & 0,75 & Rendah \\
3. & $10<\mathrm{MS} \leq 15$ & 1,00 & Sedang \\
4. & $15<\mathrm{MS} \leq 20$ & 1,25 & Tinggi \\
5. & MS $>20$ & 1,50 & Sangat tinggi \\
\hline & Sumber: Peraturan Menhut RI No 60 2014
\end{tabular}

Sumber: Peraturan Menhut RI No.60 2014

Pemantauan banjir bertujuan untuk mengetahui frekuensi saat terjadi banjir. Data ini didapatkan dari adanya laporan terjadinya banjir untuk mengklasifikasikan banjir dan menentukan nilai serta skor. Berikut ini kriteria pada penilaian kejadian banjir pada Tabel 4.

Tabel 4. Kriteria penilaian kejadian banjir

\begin{tabular}{|c|c|c|c|}
\hline No. & Frekuensi Banjir & Skor & $\begin{array}{l}\text { Kualifikasi } \\
\text { Pemulihan }\end{array}$ \\
\hline 1. & Tidak pernah & 0,5 & $\begin{array}{l}\text { Sangat } \\
\text { rendah }\end{array}$ \\
\hline 2. & 1 kali dalam 5 tahun & 0,75 & Rendah \\
\hline 3. & 1 kali dalam 2 tahun & 1,00 & Sedang \\
\hline 4. & 1 kali tiap tahun & 1,25 & Tinggi \\
\hline 5. & Lebih dari 1 kali dalam 1 tahun & 1,50 & $\begin{array}{l}\text { Sangat } \\
\text { tinggi }\end{array}$ \\
\hline
\end{tabular}

Sumber: Peraturan Menhut RI No.60 2014

Adanya penambahan penduduk dan pengalihan fungsi lahan pada daerah aliran sungai, maka penggunaan air tiap tahunnya akan mengalami peningkatan, sedangkan ketersediaan air mengalami penurunan. Hal tersebut mengakibatkan daya dukungdaerah aliran sungai makin kritis. Kebutuhan airn digunakan manusia, yaitu untuk rumah tangga, industri, peternakan, perdagangan, pertanian, hidran, pariwisata, pembangkit tenaga listrik, dan lain-lain. Kebutuhan air didapatkan dari proyeksi penduduk. Dalam menghitung indeks penggunaan air dapat digunakan rumus persamaan (5). 


$$
\text { IPA }=\frac{\text { Total Kebutuhan air }}{\text { ketersediaan air }}
$$

Dimana, kebutuhan air (m3) adalah jumlah air yang dikonsumsi selama satu tahun (tahunan) untuk berbagai keperluan diantaranya pertanian, air baku untuk rumah tangga, sosial dan industri, serta kebutuhan lainnya. Persediaan air (m3) adalah jumlah air yang tersedia di sungai yang didapat dari hasil pengukuran. Pemakaian air sungai Jangkok didominasi untuk keperluan irigasi. Terdapat 7 bendung di sepanjang aliran sungai Jangkok dengan luas daerah layanan seperti disajikan pada Tabel 5.

Tabel 5. Kriteria penilaian Indeks Penggunaan Air (IPA)

\begin{tabular}{|c|c|c|c|}
\hline $\begin{array}{l}\mathrm{N} \\
\mathrm{O} .\end{array}$ & Nilai IPA & Skor & $\begin{array}{l}\text { Kualifikasi } \\
\text { Pemulihan }\end{array}$ \\
\hline 1. & $\mathrm{IPA} \leq 0,25$ & 0,50 & Sangat rendah \\
\hline 2. & $0,25<\mathrm{IPA} \leq 0,50$ & 0,75 & Rendah \\
\hline 3. & $0,50<\mathrm{IPA} \leq 0,75$ & 1,00 & Sedang \\
\hline 4. & $0,75<\mathrm{IPA} \leq 1,00$ & 1,25 & Tinggi \\
\hline 5. & IPA $>1,00$ & 1,50 & Sangat Tinggi \\
\hline
\end{tabular}

\section{Hasil dan Pembahasan \\ Debit Sungai}

Pengukuran lebar, luas penampang serta kedalaman sungai pada penelitian ini dengan mengukur pada jembatan di sisi kiri serta kanan sungai. Pengukuran debit aliran sungai dilakukan dengan alat current meter, sedangkan pengukuran luas penampang menggunakan kayu dan meteran. Berikut ini merupakan Tabel 6 Data Hidrolik Sungai.

Tabel 6. Data hidrolik Sungai Gedek

\begin{tabular}{lllll}
\hline Lokasi & $\begin{array}{l}\text { Lebar } \\
(\mathrm{m})\end{array}$ & $\begin{array}{l}\text { Luas } \\
\text { Penampang } \\
\left(\mathrm{m}^{3}\right)\end{array}$ & $\begin{array}{l}\text { Kecepatan } \\
(\mathrm{m} / \text { detik })\end{array}$ & $\begin{array}{l}\text { Debit Aliran } \\
\left(\mathrm{m}^{3} / \text { detik }\right)\end{array}$ \\
\hline S1 & 5,35 & 6,36 & 0,2 & 1,272 \\
S2 & 5,7 & 7,83 & 0,2 & 1,566 \\
S3 & 7,95 & 12,105 & 0,2 & 2,421 \\
S4 & 12,05 & 27,18 & 0,4 & 10,872 \\
S5 & 12,66 & 27,489 & 0,4 & 10,9956 \\
\hline \multicolumn{5}{l}{ Sumber: Data primer, 2021 }
\end{tabular}

\section{Kualitas Air}

Analisis daya tampung beban pencemaran pada penelitian ini fokus pada kualitas air sungai akan yang dianalisis selanjutnya dilakukan perhitungan daya tampung beban pencemaran pada tiap parameter. Hasil pengujian kualitas air dapat dilihat pada Tabel 7.

Tabel 7. Kualitas air berdasarkan Baku Mutu Kelas I

\begin{tabular}{|c|c|c|c|c|c|c|c|}
\hline \multirow[t]{2}{*}{ Parameter } & \multirow[t]{2}{*}{ Satuan } & \multicolumn{5}{|c|}{ Lokasi Pengambilan Sampel } & \multirow{2}{*}{$\begin{array}{c}\text { Baku } \\
\text { Mutu } \\
\text { Kelas I }\end{array}$} \\
\hline & & $\mathrm{S} 1$ & $\mathrm{~S} 2$ & S3 & S4 & S5 & \\
\hline $\begin{array}{c}\text { Suhu } \\
\text { pH }\end{array}$ & $\begin{array}{c}{ }^{\circ} \mathrm{C} \\
\text { Tidak ada }\end{array}$ & $\begin{array}{l}29 \\
7,3\end{array}$ & $\begin{array}{c}31 \\
7,3\end{array}$ & $\begin{array}{l}30 \\
7,3\end{array}$ & $\begin{array}{l}30 \\
7,5\end{array}$ & $\begin{array}{c}31 \\
7,5\end{array}$ & $\begin{array}{c}\text { Deviasi } 3 \\
6-9\end{array}$ \\
\hline COD & $\mathrm{Mg} / \mathrm{L}$ & 6,473 & 6,0804 & 6,95535 & 10,7909 & 20,3917 & 10 \\
\hline BOD & $\mathrm{Mg} / \mathrm{L}$ & $\begin{array}{c}0,567 \\
5\end{array}$ & 0,113 & 0,5675 & 1,022 & 2,689 & 2 \\
\hline TSS & $\mathrm{Mg} / \mathrm{L}$ & 146,5 & 282 & 248 & 190 & 326 & 40 \\
\hline DO & $\mathrm{Mg} / \mathrm{L}$ & 5,5 & 4,05 & 4,55 & 2,55 & 2,5 & 6 \\
\hline Amonia & $\mathrm{Mg} / \mathrm{L}$ & $\begin{array}{c}0,037 \\
55\end{array}$ & $\begin{array}{c}0,0739 \\
5\end{array}$ & 0,06645 & 0,3915 & $\mathbf{0 , 8 4 7}$ & 0,1 \\
\hline
\end{tabular}

( Keterangan : Hasil yang bercetak tebal artinya melebihi batas yang dipersyaratkan ) Sumber: Hasil analisis, 2021 
Tabel 8. Kualitas air berdasarkan Baku Mutu Kelas II

\begin{tabular}{cccccccc}
\hline Parameter & Satuan & \multicolumn{5}{c}{ Lokasi Pengambilan Sampel } & \begin{tabular}{c} 
Baku \\
Mutu \\
\cline { 3 - 7 }
\end{tabular} \\
\cline { 3 - 7 } & & S1 & S2 & S3 & S4 & S5 & Kelas II \\
\hline Suhu & ${ }^{\circ} \mathrm{C}$ & 29 & 31 & 30 & 30 & 31 & Deviasi 3 \\
pH & Tidak ada & 7,3 & 7,3 & 7,3 & 7,5 & 7,5 & $6-9$ \\
COD & $\mathrm{Mg} / \mathrm{L}$ & 6,473 & 6,0804 & 6,95535 & 10,7909 & 20,3917 & 25 \\
BOD & $\mathrm{Mg} / \mathrm{L}$ & 0,5675 & 0,113 & 0,5675 & 1,022 & 2,689 & 3 \\
TSS & $\mathrm{Mg} / \mathrm{L}$ & $\mathbf{1 4 6 , 5}$ & $\mathbf{2 8 2}$ & $\mathbf{2 4 8}$ & $\mathbf{1 9 0}$ & $\mathbf{3 2 6}$ & 50 \\
DO & $\mathrm{Mg} / \mathrm{L}$ & 5,5 & 4,05 & 4,55 & $\mathbf{2 , 5 5}$ & $\mathbf{2 , 5}$ & 4 \\
Amonia & $\mathrm{Mg} / \mathrm{L}$ & 0,03755 & 0,07395 & 0,06645 & $\mathbf{0 , 3 9 1 5}$ & $\mathbf{0 , 8 4 7}$ & 0,2 \\
\hline
\end{tabular}

(Keterangan : Hasil yang bercetak tebal artinya melebihi batas yang dipersyaratkan) Sumber: Hasil analisis, 2021

Tabel 9. Kualitas air berdasarkan Baku Mutu Kelas III

\begin{tabular}{cccccccc}
\hline $\begin{array}{c}\text { Paramet } \\
\text { er }\end{array}$ & Satuan & \multicolumn{5}{c}{ Lokasi Pengambilan Sampel } & $\begin{array}{c}\text { Baku } \\
\text { Mutu } \\
\text { Kelas III }\end{array}$ \\
\cline { 3 - 7 } & & S1 & S2 & S3 & S4 & S5 \\
Rata-rata & Rata-rata & Rata-rata & Rata-rata & Rata-rata & \\
\hline Suhu & ${ }^{\circ} \mathrm{C}$ & 29 & 31 & 30 & 30 & 31 & Deviasi 3 \\
pH & Tidak ada & 7,3 & 7,3 & 7,3 & 7,5 & 7,5 & $6-9$ \\
COD & $\mathrm{Mg} / \mathrm{Lt}$ & 6,473 & 6,0804 & 6,95535 & 10,7909 & 20,3917 & 40 \\
BOD & $\mathrm{Mg} / \mathrm{Lt}$ & 0,5675 & 0,113 & 0,5675 & 1,022 & 2,689 & 6 \\
$\mathrm{TSS}$ & $\mathrm{Mg} / \mathrm{Lt}$ & $\mathbf{1 4 6 , 5}$ & $\mathbf{2 8 2}$ & $\mathbf{2 4 8}$ & $\mathbf{1 9 0}$ & $\mathbf{3 2 6}$ & 100 \\
$\mathrm{DO}$ & $\mathrm{Mg} / \mathrm{Lt}$ & 5,5 & 4,05 & 4,55 & $\mathbf{2 , 5 5}$ & $\mathbf{2 , 5}$ & 3 \\
Amonia & $\mathrm{Mg} / \mathrm{Lt}$ & 0,03755 & 0,07395 & 0,06645 & 0,3915 & $\mathbf{0 , 8 4 7}$ & 0,5
\end{tabular}

(Keterangan : Hasil yang bercetak tebal artinya melebihi batas yang dipersyaratkan) Sumber: Hasil analisis, 2021

Tabel 10. Kualitas air berdasarkan Baku Mutu Kelas IV

\begin{tabular}{|c|c|c|c|c|c|c|c|}
\hline \multirow[t]{2}{*}{ Parameter } & \multirow[t]{2}{*}{ Satuan } & \multicolumn{5}{|c|}{ Lokasi Pengambilan Sampel } & \multirow{2}{*}{$\begin{array}{l}\text { Baku Mutu } \\
\text { Kelas IV }\end{array}$} \\
\hline & & S1 & S2 & S3 & S4 & S5 & \\
\hline Suhu & ${ }^{\circ} \mathrm{C}$ & 29 & 31 & 30 & 30 & 31 & Deviasi 3 \\
\hline $\mathrm{pH}$ & Tidak ada & 7,3 & 7,3 & 7,3 & 7,5 & 7,5 & $6-9$ \\
\hline COD & $\mathrm{Mg} / \mathrm{L}$ & 6,473 & 6,0804 & 6,95535 & 10,7909 & 20,3917 & 80 \\
\hline BOD & $\mathrm{Mg} / \mathrm{L}$ & 0,5675 & 0,113 & 0,5675 & 1,022 & 2,689 & 12 \\
\hline TSS & $\mathrm{Mg} / \mathrm{L}$ & 146,5 & 282 & 248 & 190 & 326 & 400 \\
\hline DO & $\mathrm{Mg} / \mathrm{L}$ & 5,5 & 4,05 & 4,55 & 2,55 & 2,5 & 1 \\
\hline Amonia & $\mathrm{Mg} / \mathrm{L}$ & 0,03755 & 0,07395 & 0,06645 & 0,3915 & 0,847 & - \\
\hline
\end{tabular}

(Keterangan : Hasil yang bercetak tebal artinya melebihi batas yang dipersyaratkan) Sumber: Hasil analisis, 2021

a. Suhu

Air yang baik yaitu yang mempunyai suhu optimal pada suhu udara $\left(20^{\circ} \mathrm{C}\right.$ hingga $\left.30^{\circ} \mathrm{C}\right)$. Perairan yang telah tercemar memiliki temperatur di bawah ataupun diatas suhu udara. Pengukuran suhu dilakukan secara langsung pada saat pengambilan sampel. 
Suhu air terendah yaitu pada stasiun 1 dan yang tertinggi yaitu pada stasiun 2 dan stasiun 5 . Suhu yang tinggi dikarenakan oleh intensitas cahaya matahari yang masuk ke dalam air sungai tinggi dimana sungai merupakan area yang cukup terbuka serta terpapar cahaya matahari secara langsung. Intensitas radiasi cahaya matahari dan kerapatan vegetasi disekitar daerah aliran sungai dapat memengaruhi suhu air. Intensitas radiasi cahaya matahari yang tinggi akan menyebabkan suhu air semakin tinggi. Vegetasi memiliki fungsi diantaranya yaitu sebagai pengatur kelembaban udara dan suhu, penyerap O2, dan pemasok oksigen. Mempunyai fungsi ekologi seperti untuk pengaturan kelembaban dan suhu udara, penyerap $\mathrm{CO} 2$, pemasok oksigen [2]. Pada baku mutu air kelas I, II, III, IV parameter suhu masih memenuhi dan dapat digunakan sebagaimana peruntukannya.

b. $\mathrm{pH}$

Pengukuran $\mathrm{pH}$ dilakukan secara langsung di lapangan pada saat pengambilan sampel. Nilai $\mathrm{pH}<4$ sebagian besar matinya tumbuhan air yang diskarenakan tidak toleran terhadap $\mathrm{pH}$ rendah. Berikut ini hasil pengukuran $\mathrm{pH}$.

Berdasarkan hasil pengukuran $\mathrm{pH}$ diperoleh nilai $\mathrm{pH}$ terendah 7,3 yaitu pada stasiun 1,2, dan 3 , sedangkan $\mathrm{pH}$ tertinggi pada stasiun 4 dan stasiun 5. Nilai $\mathrm{pH}$ yang rendah menandakan bahwa terjadi penurunan kualitas air yang akan berdampak pada kehidupan biota dalam air. Perubahan ini dapat menyebabkan kematian pada biota air, dikarenakan terganggunya jaringan di air. Nilai $\mathrm{pH}$ dipengaruhi oleh fluktuasi kandungan $\mathrm{CO} 2$ ataupun $\mathrm{O} 2$. Pada umumnya perairan dianggap tercemar apabila nilai $\mathrm{pH}<4,8$ dan 9,2 [2]. Parameter $\mathrm{pH}$ masih memenuhi baku mutu air kelas I, II, III, IV, sehingga dapat digunakan sebagaimana peruntukannya.

c. BOD

BOD adalah kebutuhan oksigen biologi oleh makhluk hidup di dalam air. Nilai BOD yang kecil berarti kualitas air makin baik dikarenakan kebutuhan oksigen yang sedikit oleh mikroorganisme di air dalam penguraian limbah [8].

Nilai BOD di Sungai Gedek yaitu berkisar antara 0,113 mg/l hingga 2,685 mg/l dengan nilai BOD terendah yaitu pada stasiun 2 dan nilai BOD tertinggi yaitu pada stasiun 4 dan stasiun 5 . Konsentrasi BOD saling berhubungan dengan proses dekomposisi yaaitu pada kotoranatau sampah organik, menyebabkan beberapak bakteri membutuhkan oksigen di perairan pada proses aerobik. Nilai BOD yang tinggi menunjukkan kandungan bahan organik pada perairan juga tinggi. Adanya organisme yang berperan dalam melakukan proses dekomposisi pada unsur-unsur yang dapat mencemari peraran. Oksigen terlarut pada perairan dapat menopang organisme dalam melakukan kegiatan. Kebutuhan oksigen merupakan proses dekomposisi yang dilakukan secara biologis menggunakan oksigen [2].Nilai BOD pada kelas I melebihi baku mutu pada stasiun 5 yaitu sebesar $2,685 \mathrm{mg} / \mathrm{l}$. Pada kelas II, III, IV nilai BOD yang diperoleh masih memenuhi baku mutu, sehingga dapat digunakan sebagaimana peruntukannya.

d. COD

Nilai COD adalah jumlah oksigen dimana digunakan untuk keperluan dalam proses oksidasi pada zat organik dan terurai dengan mudah secara biologi ataupun yang sulit untuk diuraikan. Nilai COD menyatakan jumlah bahan organik yang ada [9].

Hasil Pengukuran diperoleh nilai COD terendah yaitu pada stasiun 1 dan stasiun 2, sedangkan nilai COD tertinggi yaitu pada stasiun 5. Pada kelas I di stasiun 4 dan stasiun 5 menunjukkan bahwa melebihi baku mutu, namun pada kelas II, III, IV masih memenuhi baku mutu. Sehingga tidak dapat digunakan untuk air minum, namun dapat digunakan untuk peruntukan yang lain.

e. DO

Oksigen terlarut adalah jumlah oksigen terlarut di dalam air. Oksigen terlarut adalah salah satu faktor yang sangat penting pada ekosistem air dan diperlukan dalam proses respirasi oleh biota air sangat terbatas [9].

Berdasarkan hasil analisis, parameter DO terendah yaitu pada stasiun 4 dan stasiun 5, sedangkan nilai DO tertinggi yaitu pada stasiun 1. Pada kelas I di semua stasiun melebihi baku mutu yaitu $6 \mathrm{mg} / \mathrm{l}$, pada kelas II, III di stasiun 4 dan 5 melebihi baku mutu yaitu sebesar $4 \mathrm{mg} / \mathrm{lt}$ dan $3 \mathrm{mg} / \mathrm{lt}$, pada baku mutu kelas IV nilai DO tidak melebihi baku mutu, sehingga dapat digunakan sesuai peruntukannya.

f. TSS

Padatan tersuspensi merupakan material tersuspensi yang dapat tertahan di saringan pada diameter sebesar $0,45 \mu \mathrm{m}$. Padatan tersuspensi terdiri dari pasir halus dan lumpur yang dapat disebabkan adanya kikisan tanah maupun adanya erosi yang terbawa oleh aliran, hal tersebut 
mengakibatkan penurunan laju fotosintesis fitoplankton. Nilai TSS tertinggi yaitu pada stasiun 5 dan nilai TSS yang terendah yaitu pada stasiun 1 . Hasil analisis yang menjelaskan bahwa hasil dari parameter TSS sangat tinggi yang berada pada di semua stasiun, hal ini menjelaskan bahwa TSS melebihi baku mutu kelas I, II, III, IV di semua stasiun. Meningkatnya nilai TSS disebabkan oleh pengalihan fungsi lahan di DAS menjadi pemukiman, sehingga material tanah masuk ke dalam arus sungai melalui run off [9].

g. Amonia

Kandungan amonia yang baik untuk kehidupan biota air yaitu kurang dari 1 ppm. Apabila melebihi menunjukkan bahwa perairan tersebut tercemar. Hasil Analisis Parameter Amonia dapat dilihat pada Tabel 7. Berdasarkan hasil yang didapatkan dari analisa tabel diatas dapat dijelaskan nilai Amonia yang paling tinggi di stasiun 5 sebesar $0,847 \mathrm{mg} / \mathrm{l}$ dan nilai Amonia paling rendah yaitu pada stasiun 1. Berdasarkan kelas I dan II bahwa pada stasiun 4 dan stasiun 5 melebihi baku mutu serta pada kelas III dan IV memenuhi baku mutu. Sehingga dapat dikatakan bahwa pada perairan Sungai Gedek tidak dapat digunakan untuk air minum dan pariwisata air pada stasiun 4 dan stasiun 5, namun dapat digunakan untuk perikanan dan pertamanan pada semua stasiun [9].

\section{Daya Tampung Beban Pencemaran}

Daya tampung beban pencemaran merupakan suatu kemampuan pada suatu perairan untuk menerima masukan beban pencemaran yang tanpa mengakibatkan perairan tersebut tercemar. Perhitungan dilakukan dengan menentukan bebap pencemar pada parameter BOD, DO, TSS, COD, dan Amonia. Perhitungan juga dilakukandengan menentukan beban pencemar maksimum berdasarkan pada baku mutu kelas 1, 2, 3, 4 PP No. 22 Tahun 2021. Nilai Beban pencemar maksimum dan terukur dapat dilihat pada Tabel 11.

Tabel 11. Nilai beban pencemar maksimum dan terukur

\begin{tabular}{ccccccc}
\hline Parameter & Satuan & \multicolumn{5}{c}{ BPM } \\
& & I & II & III & IV & \\
\hline DO & Mg/L & $5.700,12$ & $3.800,08$ & $2.850,06$ & 950,02 & $2.375,05$ \\
COD & $\mathrm{Mg} / \mathrm{L}$ & $9.500,2$ & $23.750,496$ & $38.000,80$ & $76.000,59$ & $19.372,52$ \\
BOD & $\mathrm{Mg} / \mathrm{L}$ & $1.900,04$ & $2.850,06$ & $5.700,12$ & $11.400,24$ & $2.699,0063$ \\
TSS & $\mathrm{Mg} / \mathrm{L}$ & $38.000,79$ & $47.500,992$ & $95.001,984$ & $380.007,936$ & 309.706 \\
Amonia & $\mathrm{Mg} / \mathrm{L}$ & 95,002 & 190,0039 & 475,01 & 950,02 & 759,0658 \\
\hline
\end{tabular}

Sumber: Hasil analisis, 2021

Kadar beban pencemar apabila memenuhi baku mutu serta daya tampung bebna pencemaran maka menunjukkan nilai positif, sehingga beban pencemar dalam air masih memiliki daya tampung beban pencemaran. Sebaliknya, konsentrasi baku mutu serta daya tampung beban pencemaran yang melebihi maka bernilai negative, sehingga beban pencemar di dalam air telah masih melebihi daya tampung beban pencemaran dan sungai tersebut tidak memiliki kemampuan untuk menerima beban pencemar yang masuk dalam air [10].

Tabel 12. Daya tampung beban pencemaran

\begin{tabular}{ccccc}
\hline Parameter & \multicolumn{4}{c}{ Daya Tampung Beban Pencemaran } \\
\cline { 2 - 5 } & I & II & III & IV \\
COD & $\mathbf{- 9 . 8 7 2 , 3 2}$ & $4.377,976$ & $18.628,28$ & $56.628,07$ \\
Amonia & $\mathbf{- 6 6 4 , 0 6}$ & $\mathbf{- 5 6 9 , 0 6 1 9}$ & $\mathbf{- 2 8 4 , 0 5 5 8}$ & 190,9542 \\
DO & $\mathbf{3 . 3 2 5 , 0 7}$ & $\mathbf{1 . 4 2 5 , 0 8}$ & $\mathbf{4 7 5 , 0 1}$ & $-1.425,03$. \\
TSS & $\mathbf{- 2 7 1 . 7 0 5 , 2 1}$ & $\mathbf{- 2 6 2 . 2 0 5 , 0 0 8}$ & $\mathbf{- 2 1 4 . 7 0 4 , 0 1 6}$ & $70.301,963$ \\
BOD & $\mathbf{- 7 9 9 , 0 0 6 3}$ & 151,0537 & 3001,1137 & $8.701,2337$ \\
\hline
\end{tabular}

(Keterangan : Hasil yang bercetak tebal artinya melebihi batas yang dipersyaratkan) Sumber: Hasil analisis, 2021

Berdasarkan perhitungan yang telah dilakukan nilai daya tampung beban pencemaran pada kelas I yaitu pada parameter DO, BOD, TSS, COD, Amonia, dan TSS tidak memiliki daya tampung beban pencemaran masing-masing yaitu sebesar 3.325,07 mg/l, -9.872,32 mg/l, -799,0063 mg/l, -271.705,21 
mg/l, -664,06 mg/l. Pada kelas II yang melebihi yaitu parameter DO, TSS, dan Amonia masing-masing sebesar $1.425,08 \mathrm{mg} / \mathrm{l},-262.704,016 \mathrm{mg} / \mathrm{l},-569,0619 \mathrm{mg} / \mathrm{l}$. Pada kelas III yang melebihi yaitu pada parameter DO, TSS, dan Amonia masing-masing sebesar 475,01 mg/l, -214.704,016 mg/l, -284,0558 mg/l. Pada kelas IV semua parameter memenuhi daya tampung beban pencemaran.

\section{Daya Dukung (Kualitas, Kuantitas, dan Kontinuitas Air/Tata Air)}

Hasil akhir dari penilaian kondisi tata air DAS dilakukan dengan menjumlahkan hasil kali skor yang diperoleh dengan bobot masing-masing sub kriteria, kemudian dibagi total prosentase bobot yaitu $20 \%$. Rekapitulasi hasil akhir dari penilaian kondisi tata air Sungai Gedek ditunjukkan pada Tabel 13.

Tabel 13. Penilaian kondisi tata air Sungai Gedek

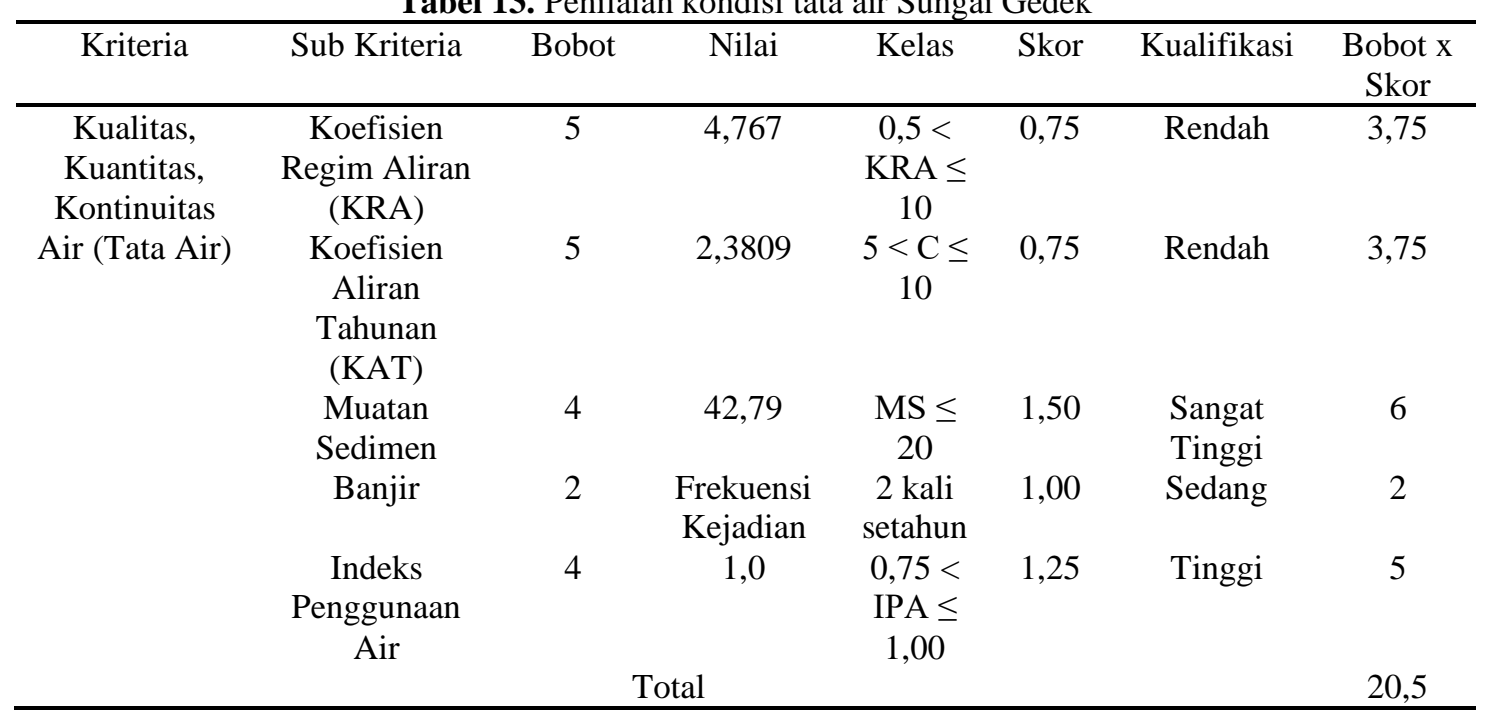

Sumber: Hasil analisis, 2021

Salah satu penilaian kekritisan daerah aliran sungai yaitu kualitas, kuantitas, dan kontinuitas (tata air), yang mempunyai bobot $20 \%$ dari keseluruhan nilai daya dukung daerah aliran sungai [1]. Apabila nilai kondisi tata air daerah aliran sungai mendapat nilai $20,5 \%$ maka terhadap bobot $20 \%$, nilai akhir dari kondisi tata air daerah aliran sungai Gedek yaitu $102,5 \%$.

Tabel 14. Klasifikasi daya dukung DAS Gedek

\begin{tabular}{lll}
\hline No. & Nilai & Kategori \\
\hline 1. & DDD $>70$ & Sangat baik \\
2. & $70<$ DDD $<90$ & Baik \\
3. & $90<$ DDD $<110$ & Sedang \\
4. & $110<$ DDD $<130$ & Buruk \\
5. & DDD $>130 \quad$ Sumber: P.61/MenhutII/2014
\end{tabular}

Hasil penilaian daya dukung pada kriteria tata air Sungai Gedek adalah 102,5 \%. Maka dapat disimpulkan bahwa kondisi daya dukung daerah aliran sungai pada kriteria tata air termasuk ke dalam kategori Sedang.

\section{Kesimpulan}

Berdasarkan hasil perhitungan dapat disimpulkan bahwa yang melebihi daya tampung beban pencemaran pada kelas I adalah DO, BOD, COD, Amonia, dan TSS masing-masing yaitu sebesar 3.325,07 $\mathrm{mg} / \mathrm{l}, \quad-799,0063 \mathrm{mg} / \mathrm{l},-9.872,32 \mathrm{mg} / \mathrm{l},-664,06 \mathrm{mg} / \mathrm{l},-271.705,21 \mathrm{mg} / \mathrm{l}$. Sedangkan pada kelas II parameter yang melebihi adalah TSS, DO dan Amonia masing-masing sebesar -262.704,016 mg/l, 1.425,08 mg/l, $569,0619 \mathrm{mg} / \mathrm{l}$. Pada kelas III parameter yang melebihi adalah TSS, DO, dan Amonia masing-masing sebesar -214.704,016 mg/l, 475,01 mg/l, -284,0558 mg/l. Pada kelas IV semua parameter memenuhi daya tampung beban pencemaran. Nilai daya dukung berdasarkan kriteria kualias, kuantitas, dan kontinuitas air (tata air) adalah $102,5 \%$ termasuk dalam kategori sedang. 


\section{Referensi}

[1] H. Saidah And L. Hanifah, "Analisis Kondisi Tata Air Untuk Pemantauan Kekritisan Daerah Aliran Sungai Jangkok," J. Tanah Dan Sumberd. Lahan, Vol. 7, No. 2, Pp. 237-248, Jul. 2020, Doi: 10.21776/Ub.Jtsl.2020.007.2.7.

[2] S. Sarminah, D. R. Anugerah, M. I. Aipassa, And A. Din, "Kualitas Air Pada DAS Bugis Dan DAS Wain Di Kawasan Hutan Lindung Sungai Wain Balikpapan," Ulin J. Hutan Trop., Vol. 4, No. 2, P. 77, Sep. 2020, Doi: 10.32522/Ujht.V4i2.4224.

[3] Peraturan Pemerintah, "Peraturan Pemerintah Nomor. 82 Tahun 2001 Tentang Pengelolaan Kualitas Air Dan Pengendalian Pencemaran Air." 2001.

[4] B. R. Widiatmono, K. D. Pavita, And L. Dewi, "Studi Penentuan Daya Tampung Beban Pencemaran Kali Surabaya Dengan Menggunakan Metode Neraca Massa," Vol. 5, No. 3, P. 8, 2017.

[5] Peraturan Pemerintah, "Peraturan Pemerintah Nomor. 22 Tahun 2021 Tentang Penyelenggaraan Perlindungan Dan Pengelolaan Lingkungan Hidup."

[6] Menteri Kehutanan, "Peraturan Menteri Kehutanan Nomor. 60 Tahun 2014 Tentang Kriteria Penetapan Daerah Aliran Sungai."

[7] Badan Standarisasi Nasional Indonesia, "Sni 6989.57.2008 Tentang Air Dan Air Limbah Dalam Metoda Pengambilan Contoh Air Permukaan." 2008.

[8] F. Abidin, S. Millang, And U. Arsyad, "Kualitas Air Sungai Pada Berbagai Tipe Penutupan Lahan Pada Sub-Sub Das Di Das Latuppa," J. Hutan Dan Masy., Vol. 11, No. 1, P. 59, Jul. 2019, Doi: 10.24259/Jhm.V11i1.5933.

[9] H. Hasan, . Farida, And A. I. Siswadi, "Analisis Kesesuaian Kualitas Airsungai Kecamatan Sambas Kabupaten Sambas Untuk Budidaya Karamba Jaring Apung (Kja)," J. Ruaya J. Penelit. Dan Kaji. Ilmu Perikan. Dan Kelaut., Vol. 6, No. 2, Jun. 2015, Doi: 10.29406/Jr.V6i2.2236.

[10] S. W. Auvaria And I. Munfarida, "Analysis Of Environmental Capacity (Water Pollution Load) In The Porong Area, Sidoarjo Regency, Ex Lapindo Mining," J. Presipitasi Media Komun. Dan Pengemb. Tek. Lingkung., Vol. 17, No. 2, Pp. 104-112, Jul. 2020, Doi: 10.14710/Presipitasi.V17i2.104-112.

[11] Kurniasari, Opy, and Lina Aprianti. "Analisis Daya Tampung Beban Pencemaran Kali Asem di Sekitar TPST Bantar Gebang dan TPA Sumur Batu." Jurnal Bumi Lestari| Vol 20.01 (2020): 22-30.

[12] R. Hasmadan, Z. Zulkifli, and I. Suprayogi, "Analisa Daya Dukung Sub Das Batang Kumu Kecamatan Rambah Hilir Kabupaten Rokan Hulu,” J. Zona, Vol. 3, No. 2, Pp. 44-50, Mar. 2021, Doi: $10.52364 / J z . V 3 i 2.37$.

[13] T. T. Putranto And N. Susanto, "Kajian Daya Tampung Dan Mutu Kelas Air Daerah Aliran Sungai Banjir Kanal Timur, Kota Semarang," J. Wil. Dan Lingkung., Vol. 7, No. 2, Pp. 121-136, Aug. 2019, Doi: 10.14710/Jwl.7.2.121-136.

[14] A. R. Wulan And K. Sirang, "Kuantitas Dan Kualitas Air Daerah Aliran Sungai Satui Kabupaten Tanah Bumbu," Vol. 01, No. 1, P. 10, 2018.

[15] M. A. R. Alfaroby And E. Wardhani, "Perhitungan Beban Pencemaran Air Sungai Cibabat Kota Cimahi Provinsi Jawa Barat," J. Serambi Eng., Vol. 6, No. 2, Mar. 2021, Doi: 10.32672/Jse.V6i2.2870. 